\title{
Oregon Subduction Zone: Venting, Fauna, and Carbonates
}

\author{
L. D. Kulm, E. Suess, J. C. Moore, B. Carson, B. T. Lewis, S. D. Ritger, \\ D. C. Kadko, T. M. Thornburg, R. W. Embley, W. D. Rugh, G. J. Massoth, \\ M. G. Langseth, G. R. Cochrane, R. L. Scamman
}

Transects of the submersible Alvin across rock outcrops in the Oregon subduction zone have furnished information on the structural and stratigraphic framework of this accretionary complex. Communities of clams and tube worms, and authigenic carbonate mineral precipitates, are associated with venting sites of cool fluids located on a fault-bend anticline at a water depth of 2036 meters. The distribution of animals and carbonates suggests up-dip migration of fluids from both shallow and deep sources along permeable strata or fault zones within these clastic deposits. Methane is enriched in the water column over one vent site, and carbonate minerals and animal tissues are highly enriched in carbon-12. The animals use methane as an energy and food source in symbiosis with microorganisms. Oxidized methane is also the carbon source for the authigenic carbonates that cement the sediments of the accretionary complex. The animal communities and carbonates observed in the Oregon subduction zone occur in strata as old as $\mathbf{2 . 0}$ million years and provide criteria for identifying other localities where modern and ancient accreted deposits have vented methane, hydrocarbons, and other nutrient-bearing fluids.

$\mathrm{T}$ The Juan de Fuca plate (Cascadia Basin) converges with the North American plate to produce a subduction complex off Oregon and Washington (Fig. 1). Near the continental margin, abundant clastic sediments load the subducting plate; a portion of these clastics is scraped off and added to the overriding plate as an accretionary sediment complex (1-4). The trench is filled with sediments, and the initial zone of deformation occurs at relatively shallow depths $(<2850 \mathrm{~m})$.

During July and August 1984, we made 15 dives with D.S.R.V. Alvin on this subduction zone. Six dives define an east-west transect extending from the abyssal plain (Cascadia Basin) across the lower continental slope (Fig. 2). Two additional dives were made approxi-

L. D. Kulm, E. Suess, D. C. Kadko, T. M. Thornburg, and W. D. Rugh are in the College of Oceanography, Oregon State University, Corvallis 97331. J. C. Moore is in the Department of Earth and Marine Sciences, University of California, Santa Cruz 95064. B. Carson and S. D. Ritger are in the Department of Geological Sciences, Lehigh University, Bethlehem, PA 180IS. B. T. Lewis and G. R. Cochrane are in the School of Oceanography, University of Washington, Seattle 98195. R. W. Embley is with the National Oceanic and Atmospheric Administration, Marine Resources Research Division, Oregon State University, Hatfield Marine Science Center, Newport 97365. G. J. Massoth is with the National Oceanic and Atmospheric Administration, Pacific Marine Environmental Laboratory, Seattle, WA 98115. M. G. Langseth is at Lamont-Doherty Geological Observatory, Palisades, NY 10964. R. L. Scamman is with Chevron U.S.A., Inc., Box 599, Denver, CO 80201 . mately $29 \mathrm{~km}$ to the north but are not shown here. The overall objective of this multidisciplinary research program was to investigate the processes of subduction-induced sediment lithification and their relation to the large-scale deformational styles of the accretionary zone. Specifically, we wished to determine how tectonic deformation affects sediment consolidation, sediment microstructure, carbonate cementation, and fluid movement.

\section{Geologic Setting}

The styles of accretion along the Oregon margin include both seaward-verging (thrust faults dipping toward the continental plate) and landward-verging (thrust faults dipping toward the oceanic plate) structures. The surface expression of the accretionary zone at the lower continental slope consists of a series of thrust ridges trending north-south and intervening basins of ponded sediment. The youngest ridges rise from 400 to $1000 \mathrm{~m}$ above the adjacent abyssal plain and were formed during the last 2.0 million years (3). The accreted and dewatered material (5) was originally deposited as a terrigenous clastic sequence on the Astoria Fan seaward of the continental slope (Fig. 1) $(3,6)$.

SeaBeam bathymetry shows that the initial deformation front consists of a series of low-relief $(\sim 40 \mathrm{~m})$ structural benches and a more landward marginal ridge that rises more than $800 \mathrm{~m}$ above the abyssal plain (Fig. 2). This ridge is incised by a small submarine canyon that locally cuts as much as $500 \mathrm{~m}$ into its seaward flank but terminates at the crest of the ridge. A second ridge is situated immediately landward of the marginal ridge and ascends $1800 \mathrm{~m}$ above the plain (Fig. 2). The steep base of the second ridge is also cut by small canyons.

The detailed structure of the central Oregon transect across the seaward-verging accretionary complex is compiled from deep-towed seismic records $(7)$ and from measurements and observations obtained during Alvin dives shown in Fig. 2. The initial deformation front is characterized by a seaward-facing escarpment that slopes $30^{\circ}$ to $40^{\circ}$ and rises 30 to $40 \mathrm{~m}$ above the abyssal plain (Fig. 2). The scarp exposes largely horizontal to gently landward-dipping strata. Talus accumulates at the base of the scarp. Alvin traverses 1421 and 1425 observed thin-bedded mudstone deposits in the outcrops above the talus that are locally broken by microfaults with displacements of several centimeters. The semiconsolidated sediment underlying the scarp crumbled when sampled by the Alvin claw. A second set of scarps exposed a few hundred meters landward apparently is the surface manifestation of a décollement that separates the deformed offscraped deposits of the lower continental slope from more gently dipping deposits being underthrust with the converging oceanic plate (Fig. 2). 
The seaward flank of the marginal ridge is characterized by intermittent rock outcrops with localized sharp ridges and precipitous scarps. The walls of the canyon also expose rock outcrops. Bedding measured from Alvin dips seaward $40^{\circ}$ to $60^{\circ}$ on the lower

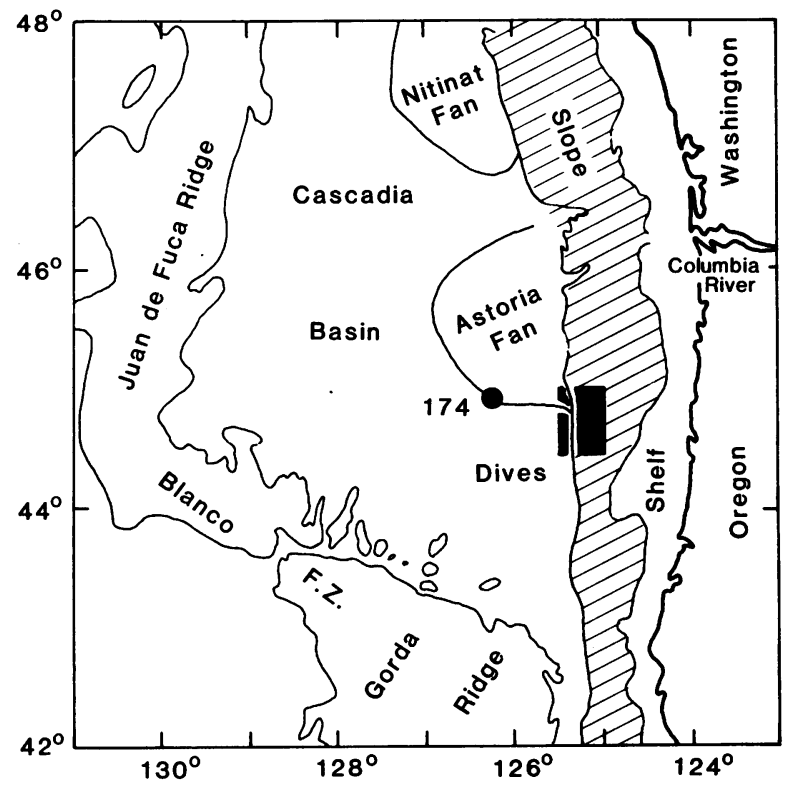

Fig. 1. Oregon subduction zone (lined pattern), Juan de Fuca plate (Cascadia Basin), and Astoria Fan. The dive area is shown by the black box, Deep Sea Drilling Project drill site 174. portion of the ridge (Fig. 2); upslope, bedding dips shallow and becomes approximately horizontal near the crest of the ridge. Near the base of the marginal ridge (dive transect 1420 in Fig. 2), friable, micaceous sandstone beds were encountered in a cliff 7 to $10 \mathrm{~m}$ high. These beds are disintegrating to form sandy debris aprons. Laminated turbidites occur higher in the section.

A deep-towed seismic reflection record shows landward-dipping reflectors on the eastern flank of the marginal ridge; they continue beneath a sediment basin lying between this and the second deformational ridge (Fig. 2). Alvin outcrop data and these geophysical records show that the marginal ridge is an anticline. By analogy to the known structures of other convergent margins $(8)$ and to fold and thrust belts on land (9), we believe that this anticline is of "faultbend" origin. The fold formed initially as a sediment package rode up a landward-dipping thrust ramp and then folded over onto a nearly horizontal sea floor.

Alvin dive 1423 revealed that the seaward flank of the second ridge (Fig. 2) exposes nearly vertical outcrops of thin to massively bedded strata that appear horizontal to gently landward-dipping. Interbedded sand and mud turbidite beds were observed, as in the marginal ridge. The slope becomes gradually gentler and rock outcrops are less frequent toward the top of the second ridge.

\section{Venting of Pore Fluids}

Animal communities. Benthic communities of tube worms and giant clams were observed during Alvin dives 1426 and 1428 along the crest of the marginal ridge (Fig. 2). Both sites are located on a

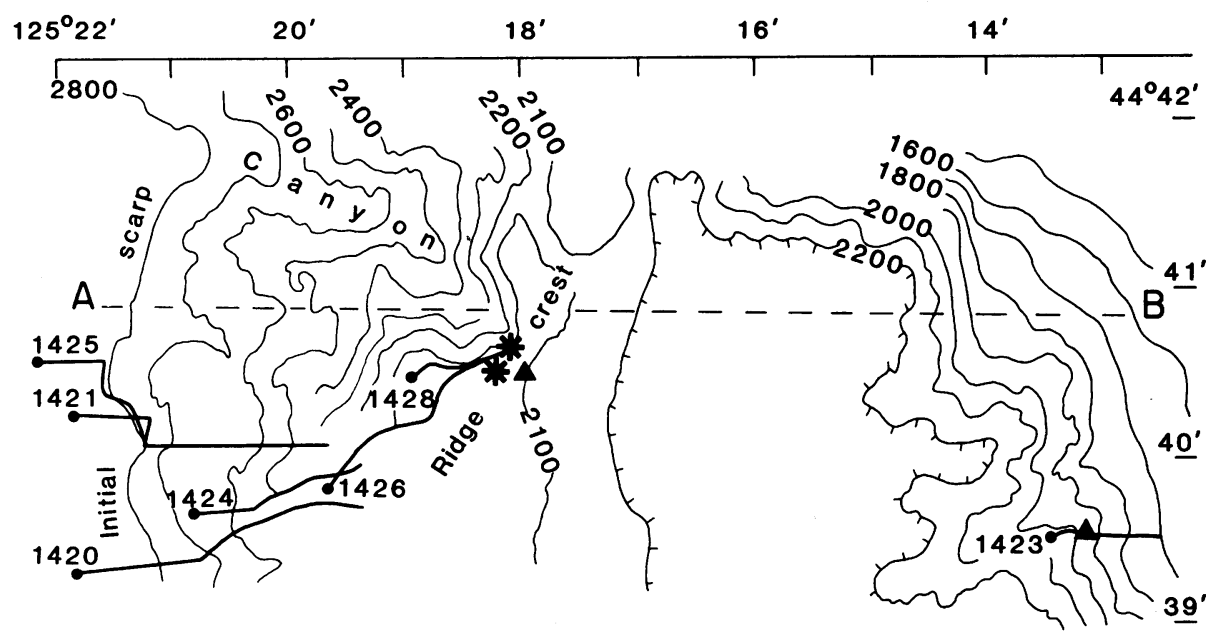

Plain + Bench + Marginal ridge $\longrightarrow$ Basin $\longrightarrow$ Second ridge

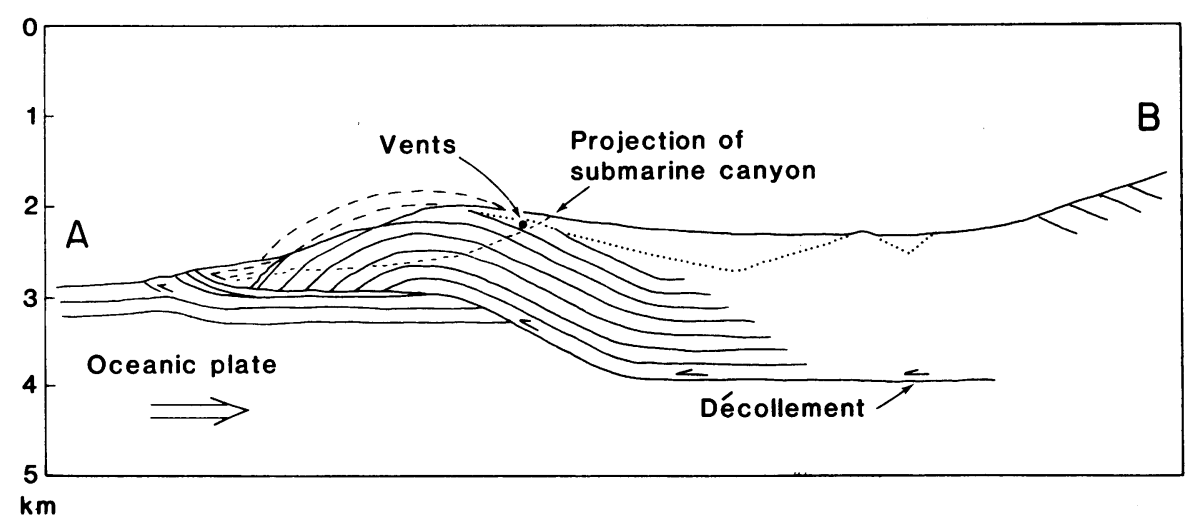

Fig. 2. (Top) Alvin dive transects and SeaBeam bathymetry map obtained by the National Oceanic and Atmospheric Administration, National Ocean Survey, aboard the Surveyor of the Oregon underthrust region. Contours are in meters; numbered dives commence at the solid dots. Asterisks indicate fluid vent sites (northern site 1428 and southern site 1426); triangles indicate carbonate chimneys at both vent sites and along dive transect 1423. (Bottom) Interpretive structural section of the deformation front along profile $\mathrm{A}-\mathrm{B}$ (dashed line). This depth section was compiled from seismic refraction and reflection data and bedding dips measured from Alvin; oceanic crust here is at $7-\mathrm{km}$ depth. 
soft sediment-covered area at $2036 \mathrm{~m}$ atop extensive rock exposures with precipitous walls where a canyon breaches the ridge crest (Fig. 3). Colonies of tube worms (phylum Pogonophora, Lamellibrachia barbami) were found at both sites $(10,11)$. The colonies are rooted either in fissures extending beneath rock ledges or in soft sediments overlying a carbonate-cemented crust. A typical colony is $\mathbf{5 0}$ to $\mathbf{8 0}$ $\mathrm{cm}$ in diameter and consists of a tangled mass of six to ten individual tubes.

Both marginal ridge localities are also marked by numerous disarticulated and partially sedimented valves of the giant white clam Calyptogena sp. $(11,12)$. Several clusters of Calyptogena sp. were encountered in growth position (Fig. 3) during dive 1428, each cluster consisting of five to six individuals. The clusters of live clams are aligned in rows that may reflect the orientation of pathways of fluid escape in the consolidating rocks underlying the thin sediment blanket. Individual specimens of another clam, Solemya sp. $(11,12)$, were observed and collected during two Alvin dives on a small incipient marginal ridge site $\sim 29 \mathrm{~km}$ to the north and were also present at vent site 1428 (Fig. 3).

The stable carbon isotope composition of animal soft-tissue parts indicates that these tube worms and giant clams metabolize a unique and extremely ${ }^{13} \mathrm{C}$-depleted carbon source, which is usually found only in $\mathrm{CH}_{4}$ and other light hydrocarbons (Table $\mathrm{l}$ ). A value of $\delta^{13} \mathrm{C}=-51.6$ per mil relative to the PDB standard, obtained from the gills of Calyptogena, is among the lowest yet reported for contemporary marine organic material. The calcareous skeletal parts of the giant clams Calyptogena and Solemya incorporate carbon from the oceanic bicarbonate reservoir $\left(\delta^{13} \mathrm{C}=-1.0\right.$ to +1.8 per mil) with only small variations (Table 1 ). Their oxygen isotope values (Table 1 ) indicate that calcification proceeds roughly in equilibrium with ambient bottom water temperatures. The same isotope characteristics and fractionations were observed for the calcareous parts of giant clams from the mid-ocean ridge sites (13-15). The carbon isotope shift toward more ${ }^{12} \mathrm{C}$-enriched values in tube worm and giant clam tissue at the margin sites, compared to the mid-ocean ridge sites, apparently reflects a different source of food. There is some indication from the oxygen isotope data (ranging from $\delta^{18} \mathrm{O}=+4.18$ to +3.49 per mil) that one clam from the Oregon deformation zone recorded higher bottom water temperatures (by about $4^{\circ} \mathrm{C}$ ) during its early years of life and incorporated slightly lighter carbon for calcification during that period (Table 1 ). This may imply episodic venting of warmer and more deeply derived pore fluids enriched in metabolic $\mathrm{CO}_{2}$.

Bottom water anomalies. Higher than normal temperatures were detected in the bottom waters overlying the deformation front. In situ recordings made near the bottom during Alvin dive 1428, in the vicinity of the clam bed and tube worm colonies, showed a positive anomaly of $+0.32^{\circ} \mathrm{C}$ at $2020 \mathrm{~m}$, approximately $14 \mathrm{~m}$ above the bottom. During the descent of the submersible through the water column, the temperature dropped gradually from $2.3^{\circ}$ to $1.7^{\circ} \mathrm{C}$ at depths between 1600 and $2100 \mathrm{~m}$, and two thin isothermal layers with temperatures of $2.15^{\circ}$ and $1.97^{\circ} \mathrm{C}$ were encountered on both descent and ascent. Near the bottom, however, the variability of temperature recordings increased significantly, and on this dive the relatively large increase was recorded during a 20-minute interval. It apparently reflects the complicated temperature structure near the crest of the nearby marginal ridge. No such anomalies were observed at other sites along the margin and abyssal plain. A similar temperature anomaly $\left(0.3^{\circ} \mathrm{C}\right)$ was recently recorded above a Calyptogena clam bed at $3830 \mathrm{~m}$ along the wall of the Nankai Trough subduction zone by the Franco-Japanese deep diving project "Kaiko" (16).

Water samples were collected in 5 -liter bottles held by Alvin directly above the animal communities and over other areas of the

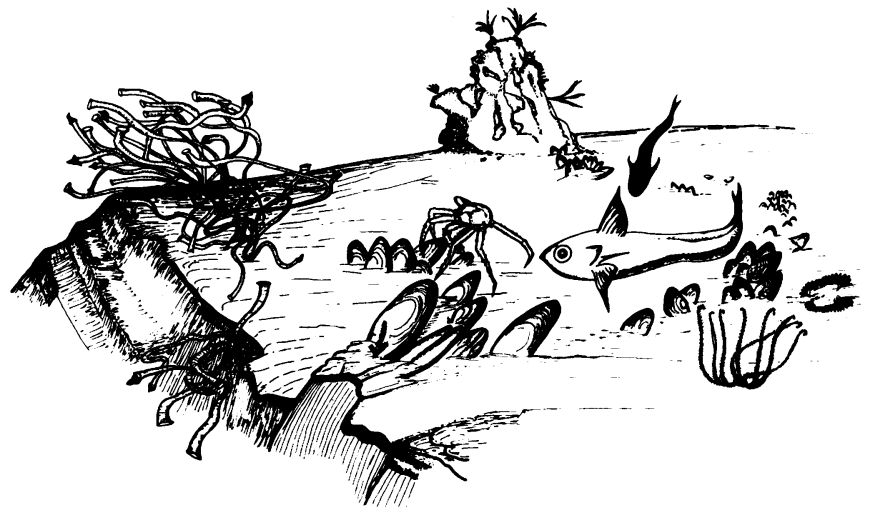

Fig. 3. Composite illustration of vent site 1428 (11). Two colonies of tube worms, Lamellibrachia barbami, occur on the ledge above the canyon wall; several clusters of live giant clams, Calyptogena sp., are aligned along presumed sites of fluid discharge; an open valve of Solemya sp. is seen on the far right; and a cone-shaped chimney structure is shown at the top. Carnivorous fishes and large crabs are attracted to the clam beds. Venting sites are at least $20 \mathrm{~m}^{2}$ in areal extent. [Courtesy of the Biological Society of Washington]

deformation front to detect the venting of pore waters by anomalous concentrations of dissolved gases. At the clam and tube worm sites of dive 1428 , the $\mathrm{CH}_{4}$ concentration was 180 to $420 \mathrm{n} /$ liter at $1 \mathrm{~m}$ above the bottom (Table 2, dives). These concentrations are three to six times greater than the $\mathrm{CH}_{4}$ concentrations found in the ambient water seaward of the deformation front (Table 2, hydrocasts) and suggest expulsion of pore fluids from the accretionary complex.

Radon-222 was sampled in the bottom waters by Alvin in several areas over the deformation front where fluid venting was suspected and by hydrocasts seaward of the front to determine background values. The ${ }^{222} \mathrm{Rn}$ concentrations in bottom waters at dive sites 1421 and 1426 appear to be anomalously high in comparison to the background sources (Table 2) of this nuclide (17). Site 1426 is the location of a tube worm colony, and site 1421 is situated above the

Table 1. Carbon and oxygen isotope values (per mil relative to PDB) of selected tissue and shell from giant clams and tube worms from the Oregon accretionary complex. We hypothesize that $\mathrm{CH}_{4}$, usually strongly enriched in ${ }^{12} \mathrm{C}$, is venting from the accretionary complex and sustains the macrobenthos via microbial symbionts capable of oxidizing $\mathrm{CH}_{4}$. Precision of $\delta^{13} \mathrm{C}$ is \pm 0.10 per mil and of $\delta^{18} \mathrm{O}$ is \pm 0.07 per mil based on National Bureau of Standards standard.

\begin{tabular}{|c|c|c|}
\hline Sample & $\delta^{13} \mathrm{C}$ & $\delta^{18} \mathrm{O}$ \\
\hline \multicolumn{3}{|c|}{ Dive 1428-04 } \\
\hline \multicolumn{3}{|l|}{ Calyptogena sp.* } \\
\hline Gills $\dagger$ & -51.6 & \\
\hline Periostracum $\dagger$ & -35.7 & \\
\hline Shell $t$ & -0.1 & +4.51 \\
\hline \multicolumn{3}{|l|}{ Shell, from lip } \\
\hline 5 to $20 \mathrm{~mm}$ & +1.5 & +4.18 \\
\hline 50 to $68 \mathrm{~mm}$ & -0.1 & +3.92 \\
\hline \multirow[t]{2}{*}{75 to $85 \mathrm{~mm}$} & -1.0 & +3.49 \\
\hline & $32-04$ & \\
\hline \multicolumn{3}{|l|}{ Solemya sp. } \\
\hline Shell $\dagger$ & +1.8 & +4.91 \\
\hline \multirow{2}{*}{ Periostracum $†$} & -31.0 & \\
\hline & $26-01$ & \\
\hline \multicolumn{3}{|c|}{ Lamellibrachia barhami Webb } \\
\hline Tissue $\dagger$ & -31.9 & \\
\hline Tube, segment & -26.7 & \\
\hline
\end{tabular}


incipient escarpments that mark the deformation front (Fig. 2). Both areas are likely locations for fluid venting.

Pore waters. Pore waters from sediments of the marginal ridge and the undeformed abyssal plain show dissolved nutrient patterns characteristic of microbial sulfate reduction. This is expected in hemipelagic sediments, but at the marginal ridge the interstitial nutrient pattern is anomalously depleted in dissolved $\mathrm{NH}_{3}$ and total $\mathrm{CO}_{2}\left(T \mathrm{TO}_{2}\right)$. We attribute this to the oxidation of $\mathrm{CH}_{4}$ because the utilization of this gas by microbial sulfate reducers generates no dissolved $\mathrm{NH}_{3}$ and only half as much $\mathrm{TCO}_{2}$ as the utilization of particulate organic carbon (POC). This is shown in reactions 1 and 2, respectively:

$$
\begin{gathered}
\mathrm{CH}_{4}+\mathrm{SO}_{4}{ }^{2-} \rightarrow \mathrm{TCO}_{2}+2 \mathrm{H}_{2} \mathrm{O}+\mathrm{S}^{2-} \\
\Delta T \mathrm{CO}_{2}:-\Delta \mathrm{SO}_{4}{ }^{2-}=1: 1 \\
2\left[\left(\mathrm{CH}_{2} \mathrm{O}\right)\left(\mathrm{NH}_{3}\right)_{x}\right]+\mathrm{SO}_{4}{ }^{2-} \rightarrow 2 T \mathrm{CO}_{2} \\
+2 \mathrm{H}_{2} \mathrm{O}+2 x \mathrm{NH}_{3}+S^{2-} \\
\Delta T \mathrm{CO}_{2}:-\Delta \mathrm{SO}_{4}{ }^{2-}=2: 1 \\
x=0.067
\end{gathered}
$$

The contributions of $\mathrm{CH}_{4}$ and POC oxidation are illustrated in Fig. 4, which shows the dissolved $\mathrm{NH}_{3}$ and $T \mathrm{CO}_{2}$ concentrations as a function of sulfate reduction for core 8306-24 from the seaward flank of the marginal ridge and core 8408-4 from the undeformed sediments of the Astoria Fan. The total depletion in $T \mathrm{CO}_{2}$ in core 8306-24 is estimated from the measured $\triangle T C \mathrm{O}_{2}$ in the pore water above that of bottom water and the loss of dissolved calcium and magnesium. Removal of calcium and magnesium results from interstitial precipitation of carbonate minerals, whereby, for each mol of cations $(\Delta \mathrm{Ca}+\Delta \mathrm{Mg}), 1 \mathrm{~mol}$ of $\mathrm{TCO}_{2}$ is used. Accordingly, $\Sigma\left(\Delta T \mathrm{CO}_{2}+\Delta \mathrm{Ca}+\Delta \mathrm{Mg}\right)$ represents the interstitial $T \mathrm{CO}_{2}$ content resulting from sulfate reduction $\left(\Delta \mathrm{SO}_{4}{ }^{2-}=\mathrm{SO}_{4}{ }^{2-}\right.$ in pore water minus $\mathrm{SO}_{4}{ }^{2-}$ in bottom water) and corrected for carbonate mineral

Table 2. Concentrations of ${ }^{222} \mathrm{Rn},{ }^{226} \mathrm{Ra}$, and $\mathrm{CH}_{4}$ in bottom waters along the Oregon accretionary complex. Measurements are from separate paired

\begin{tabular}{|c|c|c|c|}
\hline Sample & $\begin{array}{c}{ }^{222} \mathrm{Rn} \\
\text { (dpm per } \\
100 \text { liters) }\end{array}$ & $\begin{array}{c}{ }^{226} \mathrm{Ra} \\
\text { (dpm per } \\
100 \text { liters) }\end{array}$ & $\begin{array}{c}\mathrm{CH}_{4} \\
(\mathrm{n} 1 / \\
\text { liter })\end{array}$ \\
\hline \multicolumn{4}{|c|}{ Dives* } \\
\hline $\begin{array}{l}1421 \\
1421 \\
1425 \\
1426 \\
1426 \\
1427 \\
1428 \\
1428 \\
1429\end{array}$ & $\begin{array}{l}55.3 \pm 1.4 \\
52.9 \pm 2.3 \\
42.3 \pm 4.9 \\
59.4 \pm 3.6 \\
59.2 \pm 6.0 \\
43.6 \pm 1.5 \\
43.7 \pm 2.9 \\
36.8 \pm 2.6 \\
40.1 \pm 1.3\end{array}$ & $25.3 \pm 7.7$ & $\begin{array}{l}418 \\
182\end{array}$ \\
\hline \multicolumn{4}{|c|}{ Hydrocasts $\dagger$} \\
\hline $\begin{array}{l}\text { H-1-15 } \\
\text { H-1-20 } \\
\text { H-2-15 } \\
\text { H-2-20 }\end{array}$ & $\begin{array}{l}28.2 \pm 0.5 \\
15.7 \pm 0.4 \ddagger \\
25.7 \pm 0.4 \\
11.1 \pm 0.3 \ddagger\end{array}$ & $\begin{array}{l}29.9 \pm 1.8 \\
25.9 \pm 1.6 \\
22.7 \pm 1.4 \\
25.0 \pm 1.3\end{array}$ & $\begin{array}{l}66 \\
55\end{array}$ \\
\hline
\end{tabular}
sample bottles. For radon the errors are the $1 \sigma$ counting statistics. For radium the errors are either the $1 \sigma$ counting statistic or the standard deviation of duplicate runs, whichever is greater. Stripping efficiency for $\mathrm{CH}_{4}$ is 95 to 99 percent; standard error is \pm 0.2 to \pm 1.7 percent relative to the absolute gas concentration.

*Samples taken $1 \mathrm{~m}$ off bottom by Alvin. †Samples taken 15 and $20 \mathrm{~m}$ off bottom. $\quad \ddagger$ Possible leaking gas bottle. precipitation (Fig. 4). We hypothesize that the difference in yield of $\mathrm{TCO}_{2}$ between the two cores (lined area a in Fig. 4) is due to $\mathrm{CH}_{4}$ oxidation in core 8306-24. The same explanation holds for the depletion of $\mathrm{NH}_{3}$ in core 8306-24 (lined area b in Fig. 4). Therefore, the $\mathrm{NH}_{3}$ and $T \mathrm{TCO}_{2}$ concentrations in pore fluids from the marginal ridge reflect the combined contributions of each of the two substrates undergoing decomposition, that is, $\mathrm{POC}$ and $\mathrm{CH}_{4}$. By appropriately partitioning these contributions, we calculate that in the area of the marginal ridge, at a depth of $\sim 2 \mathrm{~m}$ below the sediment-water interface, as much as $\sim 30$ percent of the $T \mathrm{CO}_{2}$ results from microbial decomposition of $\mathrm{CH}_{4}$. The portion can be independently estimated from the observed $\mathrm{NH}_{3}$ and $T \mathrm{TC}_{2}$ depletions. The estimates are remarkably consistent (18).

Methane-derived authigenic carbonates. Carbonate-cemented sediments, which occur as crusts, concretions, and chimney-like structures, have been recovered repeatedly in dredges and were collected during Alvin dives from the deformation zone off Oregon. The carbonate was dominantly magnesian calcite, although dolomite and aragonite were also identified (19). Carbonate cementation occurred preferentially in the coarse-grained deposits of the accretionary complex, particularly in sand-sized turbidite layers. Initial porosities of the sediments suggest that the cementation process begins at shallow burial depths, probably within several meters of the sediment-water interface (19).

The vent areas on dives 1426 and 1428 exhibited the most striking and concentrated occurrences of carbonate deposits in the deformation front (Fig. 2). Slabs of carbonate-cemented mudstone, several centimeters thick, occurred beneath a thin terrigenous sediment cover and were frequently exposed at the sea floor as irregularly shaped, sharp-edged masses. Isolated carbonate chimneys, roughly conical and 1 to $2 \mathrm{~m}$ high, occurred above the vent site on dive transect 1428 and atop the crest of a canyon wall on transect 1423. They resemble house-of-cards structures in that they are built of sharp-edged plates fused together in a jagged mass.

Dissolution features include surficial grooves, pits, and holes. The carbonate cements of dredged rocks from the deformation front and the crusts and chimney structures recovered by Alvin at the vent sites are highly enriched in ${ }^{12} \mathrm{C}$ and have positive $\delta^{18} \mathrm{O}$ values (Table 3 ) (20). The enrichment of ${ }^{12} \mathrm{C}$ indicates that the carbonate of the cements, crusts, and chimneys is overwhelmingly derived from $\mathrm{CH}_{4}$; the $\delta^{18} \mathrm{O}$ values indicate low temperatures of formation, consistent with precipitation at shallow depths in the sediment column.

\section{Discussion}

Evidence for venting. The venting of fluids observed to date in the Oregon subduction zone is more subtle than the highly visible plumes emitted at the "smokers" in vent fields along mid-ocean spreading ridges $(21,22)$. The mid-ocean ridge vents are characterized by jets of discharging waters with temperatures in excess of $350^{\circ} \mathrm{C}$, by sulfide chimneys, and by large communities of animals. The subduction zone venting sites off Oregon lack visible evidence of concentrated avenues of discharging pore waters, although there is indirect evidence for their diffuse discharge from the temperature, $\mathrm{CH}_{4}$, and radon anomalies in the overlying water column. These venting sites are characterized by inorganic precipitation of calcium and magnesium carbonates; the mid-ocean ridge vents are characterized by sulfide deposits. We observed in the Oregon subduction zone manifestations of a new type of venting process not previously described at a plate tectonic boundary.

One notable similarity between the two types of vents, however, is the presence of large benthic organisms. Most of the organisms discovered at the subduction zone venting sites appear to be either 
the same genera or genera closely related to those found in the hot vents of the spreading centers. The chemosynthesis-based energy metabolism of organisms of the mid-ocean ridge hot vents is thought to be based on their capacity to metabolize, in symbiosis with microbes, $\mathrm{H}_{2} \mathrm{~S}$ emitted from the vents (23-25). We hypothesize that the clams and tube worms found in the cool vent areas of the Oregon subduction zone have successfully adapted to another type of energy metabolism, that is, the capacity to utilize dissolved $\mathrm{CH}_{4}$. Recently it was shown that a related genus of tube worm, Siboglinum sp., is equipped with strands of bacteria capable of uptake of ${ }^{14} \mathrm{CH}_{4}(26)$. The waters overlying the vent area on dive transect 1428 on the marginal ridge contain three to six times the amount of dissolved $\mathrm{CH}_{4}$ found in oceanic bottom water. There is no evidence of $\mathrm{H}_{2} \mathrm{~S}$ in this water or in the pore water samples taken in the hemipelagic sediments and accreted semiconsolidated sediments on the marginal ridge along the dive transect. Recent reports $(27,28)$ associate vestimentiferan worms and giant clams off western Florida and Louisiana with the venting of hypersaline waters. Methane and higher hydrocarbons could be the source of food for these communities as well. Dissolved nutrient patterns in the pore waters of sediments of the Oregon deformation front show evidence of microbial $\mathrm{CH}_{4}$ oxidation via reduction of sulfate. Furthermore, tube worms are rooted on or near carbonate chimneys and slabs, and the clams burrow into the thin veneer of sediment that surrounds the carbonate slabs. This close association of ${ }^{12} \mathrm{C}$-enriched carbonate cement and $\mathrm{CH}_{4}$-derived carbon in the soft tissue of the animals appears to be almost certainly the result of localized expulsion of $\mathrm{CH}_{4}$-enriched pore fluids.

Recognition of fluid expulsion zones on the lower continental slope of Oregon provides clues on the possible pathways for fluid migration within this accretionary complex $(0.44$ to 2.0 million years old). On the marginal ridge, fluids are being expelled near the breached crest of the "fault-bend" anticline and apparently have migrated up-dip along permeable zones within its landward flank (Fig. 2). Simple up-dip migration along landward-dipping structures suggests source depths of at least $1.0 \mathrm{~km}$. On the second ridge, pore fluids probably migrate along horizontal to shallow-dipping strata and are expelled at outcrops along steep canyon walls cutting its seaward flank. Living tube worm colonies were also dredged from this ridge to the south of the study area (29).

Methane-enriched pore water entrapped in sediments initially deposited on the abyssal plain (Astoria Fan in Fig. 1) appears to be the primary source of expelled fluids in the $<0.3$ million-year-old deposits of the marginal ridge. Upper Pleistocene fan deposits consist of 50- to $100-\mathrm{cm}$-thick, very fine to medium-grained unconsolidated sand turbidites with mud interbeds at Deep Sea Drilling Project drill site $174(6)$. These sediments also contain abundant $\mathrm{CH}_{4}$, which is highly enriched in ${ }^{12} \mathrm{C}\left(\delta^{13} \mathrm{C}=-80\right.$ per mil $\left.\mathrm{PDB}\right)$, confirming its microbial origin $(6,30)$. Pore fluids are expelled from these sediments as they consolidate in response to tectonic stresses induced by subduction accretion (5).

Fossil record. The high abundance of clams and tube worms in the vent community spread over several square meters at sites 1426 and 1428 off Oregon argues for similar occurrences of fossil animals in exposed accretionary complexes of ancient convergent margins. Most species of the molluskan genus Calyptogena sp., both living and fossil, are found around the Pacific rim from Japan to the Gulf of Alaska to South America (31). They also are found in the Atlantic Ocean off Africa and in the western Caribbean. Thus far ten fossil species have been recognized in sediments dating from Oligocene to Holocene age, and seven living species occur on continental margins in water depths ranging from $\sim 100$ to $2600 \mathrm{~m}$. The only species that have been studied in modern environments are the clams Calyptogena pacifica, C. kilmeri, and C. magnifica, whose soft parts
Table 3. Carbon and oxygen isotope values (per mil relative to PDB) of selected magnesian calcite cements and carbonate crusts from the Oregon marginal ridge. Samples span the entire range of $\delta^{13} \mathrm{C}$ and $\delta^{18} \mathrm{O}$ values measured on all samples recovered; additional analyses are described (20). Precision of $\delta^{13} \mathrm{C}$ is \pm 0.10 per mil and of $\delta^{18} \mathrm{O}$ is \pm 0.07 per mil, based on National Bureau of Standards standard.

\begin{tabular}{ccc}
\hline Sample & $\delta^{13} \mathrm{C}$ & $\delta^{18} \mathrm{O}$ \\
\hline & Dredged carbonate cements & \\
22 to 12 & -66.7 & 4.22 \\
16 to 2 & -51.2 & 4.31 \\
22 to 6 & -58.7 & 4.72 \\
16 to 13 & -48.7 & 3.69 \\
& Dive $1428-02$, carbonate crusts & \\
1 & -39.1 & 6.39 \\
8 & -38.6 & 6.79 \\
5 & -34.9 & 6.04 \\
\hline
\end{tabular}

resemble one another and may be adapted to symbiosis with microbes (31). Interestingly, the living specimens of Calyptogena (Calyptogena) kilmeri (Bernard) were found offshore from British Columbia, Canada, to northern California $\left(53^{\circ}\right.$ to $\left.40^{\circ} \mathrm{N}\right)$ at water depths ranging from 549 to $1464 \mathrm{~m}$. These sites share with Oregon a common tectonic setting-all are situated on the accretionary complex of the northeast Pacific subduction zone.

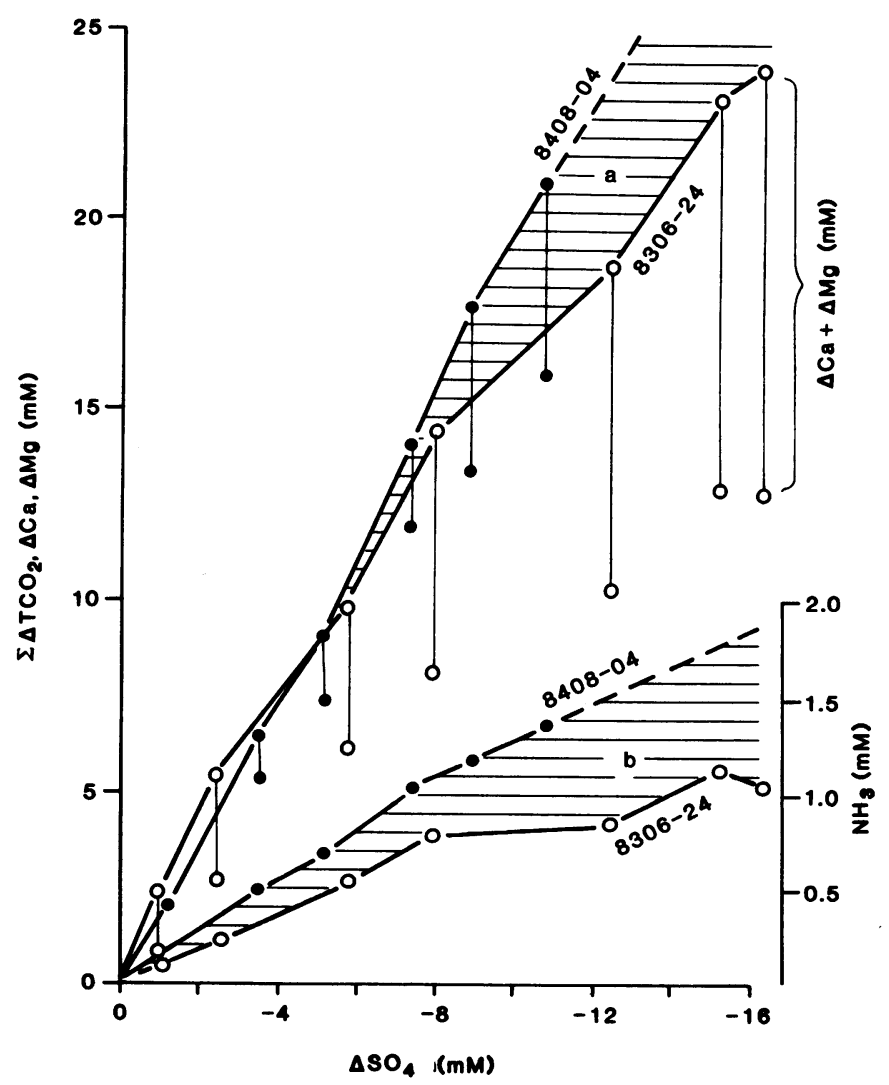

Fig. 4. Changes of concentrations of dissolved metabolites in pore waters of sediments from the subduction zone (core 8306-24) and the undeformed abyssal plain (core 8408-04). Organic matter decomposes by microbial sulfate reduction in both cores, generating $\mathrm{TCO}_{2}$ and $\mathrm{NH}_{3}$. Estimating the removal of $T \mathrm{CO}_{2}$ by carbonate mineral precipitation and then comparing the metabolite pattern shows that in core 8306-24 a more reduced carbon substrate, such as $\mathrm{CH}_{4}$ yielding less $\mathrm{TCO}_{2}$ (lined area a) and no $\mathrm{NH}_{3}$ (lined area $b$ ), is oxidized concurrently with normal sedimentary organic matter. The vertical bars indicate the addition of $(\Delta \mathrm{Ca}+\Delta \mathrm{Mg})$ to $\Delta T \mathrm{CO}_{2}$ with progressive depth in core, thereby correcting for the formation of carbonate minerals. 


\section{Global Implications}

Since our discovery of this unique biological community along the Oregon margin in August 1984, four more finds were made in circum-Pacific subduction zones during the summer of 1985 . French and Japanese scientists participating in the Kaiko Project discovered giant white clams, tentatively identified as Calyptogena sp., with the submersible Nautile in water depths of $3800 \mathrm{~m}$ at the northern end of the Nankai Trough and at $5640 \mathrm{~m}$ in the Japan Trench. Both sites are located on the landward walls of the trenches opposite the Philippine and Pacific oceanic plates, respectively (16, 32). In addition, the Japanese submersible Shinkai 2000 discovered similar mollusks and tube worm colonies in $1300 \mathrm{~m}$ of water in Sagami Bay, presumably along the Sagami Trough (16). These animals were found where thrust faulting, caused by subduction, apparently expels pore waters along fault planes in the accretionary complexes. The Nankai Trough, the Japan Trench, and the Oregon margin represent subduction zones where thick, organic-rich, terrigenous sediments occupy the trench and are off-scraped to build an accretionary complex. Another, so far unreported discovery of what appear to be species of the mollusk Calyptogena was made along the Peru continental margin in April 1985 by Kulm, Suess, and Thornburg. Three living specimens were dredged from a water depth of 3600 to $3900 \mathrm{~m}$ in an area of the margin where a large fracture cuts nearly perpendicular to the trend of the Peru continental slope. The Peruvian margin represents a subduction erosion setting where the accretionary complex is relatively small and is apparently retreating landward (33), as opposed to the subduction accretion settings of the northeast and northwest Pacific that are actively building seaward.

Our studies show that compressive tectonic stresses acting along convergent margins are especially effective in expelling $\mathrm{CH}_{4}$ and nutrient-rich pore fluids that enable organisms to adapt and evolve in this special ecosystem. Studies of subduction zones with deep submersible technology show that we are on the threshold of numerous global discoveries in convergent margins with different tectonic settings, geologic frameworks, and ages. Such studies may contribute to our understanding of the evolution and history of these dynamic and complicated plate tectonic boundaries.

\section{REFERENCES AND NOTES}

I. E. A. Silver, Mar. Geol. 13, 239 (1972)

2. B. Carson, Y. Jennwei, P. B. Myers, Jr., Geology 2, 56I (1974).

3. L. D. Kulm and G. A. Fowler, in The Geology of Continental Margins, C. A. Burk and C. L. Drake, Eds. (Springer, New York, 1974), pp. 26I-283.

4. D. R. Seely, P. R. Vail, G. G. Walton, ibid., pp. 249-260.

s. B. Carson, Mar. Geol. 24, 289 (1977).
6. L. D. Kulm et al., Eds., Init. Rep. Deep Sea Drill. Proj. 18 (1973).

7. We obtained seismic reflection records (i) by towing from a surface vessel a hydrophone streamer (designed by B. Lewis) about $100 \mathrm{~m}$ above the sea floor with a water gun source at surface or (ii) by using a hydrophone streamer mounted on Alvin with the source at the surface.

8. D. E. Karig et al., Nature (London) 304, 148 (1983).

9. J. Suppe, Am. J. Sci. 283, 684 (1983).

10. Taxonomic identification courtesy of M. L. Jones, Smithsonian Institution, Washington, DC.

II. E. Suess et al., in The Hydrothermal Vents of the Eastern Pacific: An Overview, M. L. Jones, Ed. [Bull. Biol. Soc. Washington No. 6 (1985)], p. 475.

12. Taxonomic identification courtesy of $R$. Turner, Harvard University.

13. A. J. Southward et al., Nature (London) 293, 616 (1981).

14. G. H. Rau, Science 213, 338 (1981).

I5. J. S. Killingley, W. H. Berger, K. C. MacDonald, W. A. Newman, Nature (London) 287, 218 (1980).

16. D. Swinbanks, ibid. 316, 475 (1985)

17. In seawater ${ }^{222} \mathrm{Rn}$ (half-life $=3.85$ days), which is produced from ${ }^{226} \mathrm{Ra}$ (half life $=1622$ years), ordinarily comes from two sources: (i) decay of its parent ${ }^{226} \mathrm{Ra}$, dissolved in the water and (ii) diffusion out of the sediments where it is produced from ${ }^{226} \mathrm{Ra}$ associated with sediment particles. In the bottom waters, the background level of ${ }^{226} \mathrm{Ra}$-supported radon was $25.8 \pm 3.0 \mathrm{dpm}$ per 100 liters. Diffusion of ${ }^{222} \mathrm{Rn}$ from the sediments was estimated to be $0.27 \mathrm{dpm} / \mathrm{cm}^{2}$ from flux $=\phi \cdot Q \cdot \rho(\tau D)^{1 / 2}$, where the porosity $(\phi)=0.85$ percent (by volume), dry bulk density $(\rho)=0.43 \mathrm{~g} / \mathrm{cm}^{3}$, pore water diffusion coefficient $(D)=5 \times 10^{-6}$ $\mathrm{cm}^{2} / \mathrm{sec}$, and the radon mean life $=5.5$ days. $Q$ is the radon emanation measured at $0.490 \mathrm{dpm} / \mathrm{g}$ (dry weight) [W. S. Broecker, in Symposium of Diffusion in Ocean and Fresh Water, T. Ichige, Ed. (Lamont-Doherty Geological Observatory, Palisades, $\mathrm{NY}, 1965)$, pp. II6-I45]. The combined near-bottom concentration $\left(C_{0}\right)$ from these two sources would be in the range of $\sim 35$ to $45 \mathrm{dpm}$ per 100 liters, depending on the extent of bottom turbulence:

$$
C_{0}=\left[0.27(\lambda / k)^{1 / 2}\right] \times 10^{5}+25.8 \mathrm{dpm} \text { per 100 liters }
$$

where $\lambda$ is the radon decay constant and $k$ is the turbulent diffusion coefficient in the water column.

18. The percentages of $\mathrm{TCO}_{2}$ generated by $\mathrm{CH}_{4}$ oxidation in sediment core 8306-24 were calculated for seven depth intervals based on $\mathrm{NH}_{3}$ and $\mathrm{TCO}_{2}$ deficiencies, respectively. These independent estimates are in good agreement with each other; their relative errors are large at shallow depths because of low $T \mathrm{CO}_{2}$ and $\mathrm{NH}_{3}$ concentrations and small $\mathrm{SO}_{4}{ }^{2-}$ changes. They are as follows: $36 \pm 2$ and $36 \pm 2$ percent at 175 to $180 \mathrm{~cm} ; 29 \pm 2$ and $31 \pm 2$ percent at 160 to $165 \mathrm{~cm} ; 40 \pm 5$ and $32 \pm s$ percent at 125 to $130 \mathrm{~cm} ; 24 \pm s$ and $10 \pm s$ percent at 85 to $90 \mathrm{~cm} ; 19 \pm s$ and $18 \pm s$ percent at 60 to $65 \mathrm{~cm} ; 36 \pm 20$ and $\circ \pm 20$ percent at 25 to $30 \mathrm{~cm}$; and $32 \pm 20$ and $O \pm 20$ percent at 5 to $10 \mathrm{~cm}$.

19. R. L. Scamman, thesis, Lehigh University (1981)

20. S. Ritger, B. Carson, E. Suess, Geol. Soc. Am. Bull., in press.

21. J. B. Corliss et al., Science 203, 1073 (1979).

22. J. Francheteau, Nature (London) 277, 523 (1979).

23. H. Felbeck, Science 213, 336 (1981).

24. C. M. Cavanaugh, Nature (London) 302, 5861 (1983)

25. H. W. Jannasch, in Hydrothermal Processes at Seafloor Spreading Centers, P. A. Rona et al., Eds. (Plenum, New York, 1983), pp. 677-710.

26. H. J. Flügel and R. Schmaljohann, Sarsia, in press.

27. C. K. Paull et al., Science 226, 965 (1984).

28. J. M. Brooks, M. C. Kennicutt, II, R. R. Bidigare, R. A. Fay, Eos 66, 106 (1985). 29. M. Webb, Bull. Mar. Sci. 19, 18 (1969).

30. R. D. McIver, Init. Rep. Deep Sea Drill. Proj. 18, 1013 (1973).

3I. K. J. Boss and R. D. Turner, Malacologia 20, 16I (1980).

32. D. Swinbanks, Nature (London) 315, 624 (1985).

33. R. von Huene, L. D. Kulm, J. Miller, J. Geophys. Res. 90, 5429 (1985).

34. We acknowledge the assistance of the crew members of the R/V Wecoma (Oregon State University) and R/V Atlantis $I$ (Woods Hole Oceanographic Institute); we appreciate the assistance and advice of $A$ lpin pilots and support group. We thank $\mathrm{K}$. Kelly-Hansen and A. Ungerer for carrying out the $\mathrm{CH}_{4}$ and pore water chemistry analyses, respectively. R. D. Turner identified the clams and M. L. Jones the tube worms. This project was funded by National Science Foundation grants OCE-82-I5147-OI, -02, -03 (L.D.K.) and OCE-83-15836 (J.C.M.) and National Oceanic and Atmospheric Administration grant NA-84-ABHoo030 (E.S. and D.C.K.). 


\section{Science}

\section{Oregon Subduction Zone: Venting, Fauna, and Carbonates}

L. D. KULM, E. SUESS, J. C. MOORE, B. CARSON, B. T. LEWIS, S. D. RITGER, D. C. KADKO, T. M. THORNBURG, R. W. EMBLEY, W. D. RUGH, G. J. MASSOTH, M. G. LANGSETH, G. R. COCHRANE and R. L. SCAMMAN

Science 231 (4738), 561-566

DOI: $10.1126 /$ science.231.4738.561

ARTICLE TOOLS

RELATED
CONTENT

REFERENCES

PERMISSIONS http://science.sciencemag.org/content/231/4738/561

file:/contentpending:yes

This article cites 21 articles, 5 of which you can access for free http://science.sciencemag.org/content/231/4738/561\#BIBL

http://www.sciencemag.org/help/reprints-and-permissions 